\title{
Abdominal and pelvic complications of molecular targeted therapy
}

\author{
Richard M Gore*, Robert I Silvers \\ From International Cancer Imaging Society (ICIS) 14th Annual Teaching Course \\ Heidelberg, Germany. 9-11 October 2014
}

Traditional chemotherapy is cytotoxic in nature and acts primarily by eliminating neoplastic cells. Change in tumor size, which is an indicator of change in the number of neoplastic cells, evolved into the radiologic biomarker of treatment response. The infectious, inflammatory, hemorrhagic and neoplastic complications of these therapies have been well described. Significant advances in molecular cytogenetics has led to the development of molecular targeted therapy which selectively acts on tumor cells and modifies their biologic characteristics, by affecting various cellular targets: growth factor receptors, signaling molecules, cell-cycle proteins, molecules that direct apoptosis and angiogenesis. This has required new means of assessing tumor response to therapy. Additionally, a variety of expected and unusual complications can develop in the abdomen and pelvis in these patients. This presentation highlights the imaging features of these complications which may be confusing both radiologically and clinically.

Published: 9 October 2014

Submit your next manuscript to BioMed Central and take full advantage of:

- Convenient online submission

- Thorough peer review

- No space constraints or color figure charges

- Immediate publication on acceptance

- Inclusion in PubMed, CAS, Scopus and Google Scholar

- Research which is freely available for redistribution

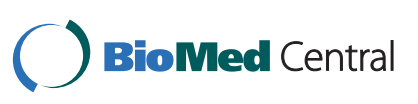

(C) 2014 Gore and Silvers; licensee BioMed Central Ltd. This is an Open Access article distributed under the terms of the Creative Commons Attribution License (http://creativecommons.org/licenses/by/4.0), which permits unrestricted use, distribution, and reproduction in any medium, provided the original work is properly cited. The Creative Commons Public Domain Dedication waiver (http://creativecommons.org/publicdomain/zero/1.0/) applies to the data made available in this article, unless otherwise stated. 